\title{
Developing Powers in Multilateral Regimes: Brazil's Foreign Policy in the Climate Change and Peace and Security Regimes
}

\author{
Felipe Leal Albuquerque \\ Institute of Social Sciences, University of Lisbon (ICS-UL), Av. Prof. Aníbal \\ Bettencourt 9, Lisbon 1600-189, Portugal \\ felipelra@gmail.com
}

Received 28 February 2017; accepted 24 September 2017

\begin{abstract}
Developing powers are able to influence the evolution of the liberal order. In their multilateral engagements, they can employ a variety of foreign policy and negotiation strategies, voice their preferences and strengthen their bargaining power. This study examines how developing powers interact with the principles and norms of multilateral regimes. It analyzes Brazil's behavior and negotiation power in the climate change and peace and security regimes. More specifically, it focuses on two concepts recently asserted by Brazil: 'concentric circles' and 'responsibility while protecting.' While the former addresses the division of responsibilities in the climate change realm, the latter approaches the norm of responsibility to protect. A comparative analysis is conducted with respect to three explanatory indicators, two domestic and one structural. One of the conclusions is that Brazil has behaved in such a way as to uphold a legalistic stance towards the global order.
\end{abstract}

* Felipe Albuquerque is a Marie Curie Fellow under the European Commission Initial Training Network (ITN) PRIMO - Power and Region in a Multipolar Order. He works as a research assistant at the Institute of Social Sciences of the University of Lisbon (ICS-UL) in Portugal. This research has received funding from the European Union's Seventh Framework Programme for research, technological development and demonstration under grant agreement no 607133 . 


\section{Keywords}

climate change - peace and security - Brazil - multilateralism - regimes - negotiation developing powers

The current global order largely reflects America's foreign policy choices. ${ }^{12}$ Established on the rubble of the League of Nations and the Second World War, it combines liberal principles and norms with multilateral institutions. ${ }^{3}$ Its prerogatives, conversely, were not written from scratch. Principles stemming from the Westphalian order, such as sovereign equality of states and balance of power, still bound and infuse interstate interactions. Amidst this setup, developing powers ${ }^{4}$ presently have more means to voice their interests and to influence outcomes.

The rise of China, India and Brazil creates a challenge to academia and to day-to-day politics. Academia struggles to explain how these powers have risen, what is distinctive about them, and to what extent they aim to alter underlying structures of the ongoing order. Many analysts tend to characterize these countries as friends or foes, which ends up misleading their foreign policies and blurring obvious differences. Placing these states within fixed categories oversimplifies reality. Secondly, as they rise, these powers manifest dissatisfaction with aspects of the present order, which can promote tensions in several arenas of global governance. They engage with such paradigms through a series of strategies in their bilateral and multilateral engagements. By and large, they endeavor to partake in decision-making instances of international institutions and to have a say in the shape of things to come.

This study elucidates how developing powers interact with the principles and norms of multilateral regimes. I maintain that their overall behavior is not predetermined, but ranges from (re)-interpretations of standing principles and norms to legalistic defenses of the status quo. As they rise, these powers enact strategies that reveal the means through which they act and which outcomes they aim to achieve. Considering these dynamics, this article explains

1 This research was funded by the European Union's Seventh Framework Programme for research, technological development and demonstration under grant agreement no. 607133.

2 On the concept of order, see Hurrell (2007).

3 Ruggie (1982) refers to multilateralism as an implicit principle.

4 The term "developing" rather than "rising" or "emerging" powers is used in this article. Nye's (2015: 76) view that "the rise of China is a misnomer; recover is more accurate" is used. The same applies to India. 
Brazil's foreign policy in the regimes of climate change and peace and security. It does so by looking into three explanatory factors, one systemic and two domestic: (i) regime structure, (ii) Brazil's domestic comparative advantages, and (iii) diplomatic expertise. Combined, these factors comprise an analytical framework that is tested against the climate change and peace and security regime cases.

As for the two case studies, developing powers are currently able to shape the evolution of several agendas, as happens with the regimes of climate change and peace and security. In the climate realm, Brazil, South Africa, India and China comprise the BASIC coalition, which altered the decision-making process that led to a post-Kyoto institutional framework. They now rank among the top emitters of greenhouse gases (GHG), which makes it imperative that talks involve a broader range of topics and actors. In the peace and security arena, developing powers not only contribute to peacekeeping operations, but also openly debate matters related to the role of the Security Council (UNSC), humanitarian intervention, and the use of force. As this study shows, such endeavors not always receive enthusiastic support.

In both areas, Brazil exerts varied degrees of influence. In the climate change regime, it promoted initiatives, including the idea of "concentric circles" that it advanced in 2014. ${ }^{5}$ Furthermore, Brazil is integrated in the BASIC and has material assets like the Amazon forest. In the peace and security realm, Brazil is a regular non-permanent member - while bidding for permanent membership of the United Nations Security Council (UNSC), and a contributor to peacekeeping troops. The country also seeks to shape international views on humanitarian intervention and protection of civilians in armed conflicts. Amid the Libyan crisis in 2011, Brasília conceived of the concept of "responsibility while protecting" (RwP), a corollary to the norm of "responsibility to protect" $(\mathrm{R} 2 \mathrm{P})$.

In this analysis, the two cases are compared to ascertain how Brazil has engaged with the principles and norms of the two respective multilateral regimes. In both cases, Brazil promoted legalistic positions that reflect the existing treaties and conventions. Rather than defending drastic changes, Brazil behaved in accordance with the status quo. One difference, though, is that while Brazil's idea of concentric circles was met with overall agreement in the climate realm, its concept of RwP encountered the distrust of relevant stakeholders and lost momentum when Brazil left the UNsc. While the analysis is focused on Brazil and the two multilateral regimes, it can open space for further interpretations

5 Concentric circles or concentric differentiation is a proposal that seeks to maintain differentiation in responsibilities between developed and developing countries. 
regarding the rise of developing powers. This study is based upon official documents from the United Nations and Brazil's Ministry of External Relations, as well as research literature on regime theory and foreign policy.

\section{Developing Powers in Multilateral Regimes}

The global shifts brought about by the 2003 Iraq war, the 2008 financial crisis, and the relative rise of developing powers rank among the most studied topics in current international relations literature. Questions revolve around the extent of the decline of the United States, whether or not countries such as China, India and Brazil seek to redesign the current order, and whether that change is occurring. Researchers examine how developing powers interact with the major principles, norms, rules and decision-making procedures. To do so, they analyze the structure of the global order as a means to subsequently investigate the multilateral behavior of developing powers. As developing states acquire increased capacity to vocalize their own preferences, alternate readings of the existing order as well as tensions over controlling the agenda will arise.

\section{The State of the Global Order}

Although the post-1945 order retains some principles from the Westphalian system of states, the current architecture is substantially distinct. Generally, it is inspired by Woodrow Wilson's liberal premises, bringing in new principles such as refraining from the threat or use of force, reliance on cooperative measures, and non-interference. Combined with these, an emphasis on human rights infuses foundational documents like the Charter of the United Nations.

Patrick (2017) points out that the current order is founded on international law, institutionalism, multilateralism, self-determination, free trade, and domestic liberty. ${ }^{6}$ The ultimate goal is the pursuit of cooperative means. Together, these elements comprise what he calls an "open world" that replaces an outmoded European order, which was marked by spheres of influence, protectionism and autarkic rules.

A plethora of jurisdictional documents complement and broaden foundational treaties on topics such as trade, non-proliferation, climate change, and peace and security. Over time, the result is a profusion of global and regional conventions with a myriad of rules that govern specific subjects. Ideally,

6 See: http://www.worldpoliticsreview.com/articles/20868/an-open-world-is-in-the-balancewhat-might-replace-the-liberal-order. 
these should be marked by a cooperative spirit. The reality, however, proves more complex, due to continued struggles for power and the perpetuation of imbalances.

Scholarship on regimes provides useful tools for analyzing the development of the global order. Regimes take place to supplement gaps and to provide bridges between realist and liberal theories (Krasner 1983). With regard to constructivism, Puchala and Hopkins (1983) argue that regimes can be nested within moderated or "Wendtian" versions of theory. The puzzling relationships between state agency and the structural buffer provided by institutions, discussed later in this article, fit well in this view.

According to Krasner's definition (1983: 1), regimes are "principles, norms, rules, and decision-making procedures around which actors' expectations converge in a given issue-area." ${ }^{7}$ Regimes are built in two phases. The first, or the static part of the concept, establishes normative components or the "principles, norms, rules, and decision-making procedures." The second addresses the dynamic element or the convergence of actors' expectations in a given issuearea, putting the normative components into motion.

The notion of convergence underscores that states' expectations do not "float in space." Principles, norms, rules and decision-making procedures enable behaviors, as a state can propose new norms and rules when defending a course of action. Alternatively, they provide limitations that constrain and ultimately sanction deviant conduct. In a nutshell, regimes are thematic partitions of the global order that both hinder and enable individual initiatives.

The concept carries a contradiction that reflects present tensions between developed and developing countries. It deals with the plausibility of change. Regimes confine such possibilities to a controlled setting, which can be understood as a conservative way to approach the likelihood of change. Whenever a country expects to alter some element of the ongoing order, it deals with a bounded scenario that is inflexible to change. That is why such a rule-based and normative-infused system carries imbalances that are hard to supersede.

\section{Developing Powers and Multilateral Regimes}

The present order includes a contradiction between its foundation and the practice of international relations. As most principles, norms, rules and decision-making procedures were established in a top-down manner, the order was exclusivist at birth. Over time, this set-up was questioned by states attempting to insert their interests in shaping the global arena. While past attempts to

7 For a definition of norms and principles, see Finnemore \& Sikkink (1998) and Hurrell (2002).

On rules and decision-making procedures, see Krasner (1983). 
promote change were met with discomfort and only achieved minor successes, novel endeavors were seen as sources of instability. The rise of developing powers reaffirms this tension.

During the Cold War, voices of discontent received only lukewarm support from developed powers. These attempts were not tied to power provisions and coalitions were plagued by rivalries, which undermined the ability of developing powers to promote change. Moreover, they were more focused on criticizing the bipolar division of the world than on promoting feasible solutions. In many cases, their proposals only reached the top of the agenda when validated by the states controlling it. ${ }^{8}$

Currently, developing powers have more room to push forward their interests. Several factors account for this shift. First, states such as China, India and Brazil enjoy more material capabilities. Second, as major powers in their respective regions, their foreign policies exert impact in their neighborhoods and propel their importance beyond their region. ${ }^{9}$ Third, developing countries exert more clout in international institutions, be it individually or through coalitions. While their quest to occupy decision-making roles remains on track, they have more means to influence the norms and principles of such arrangements. ${ }^{10}$ In recent years, for example, they have gained more voting power at the International Monetary Fund. In the climate change realm, they rank among the top emitters of GHG which makes them important stakeholders.

Views on such dynamics are far from uniform. A first group of authors, most sharing realist views, understands that newcomers tend to disturb the structures of global governance. The argument is straightforward: inasmuch as developing powers gather and apply material capabilities, conflicts will arise. Mearsheimer (2001) maintains that states endeavor to maximize their share of world power, which can prompt a return to great power politics. As the developing powers are not content with the liberal order, their positions will clash with those of the established powers. China's policies in the South China Sea illustrate this argument.

8 For instance, the so-called Third World convened within the Non-Aligned Movement and proposed a New International Economic Order. Although alluring, these calls fell short on prompting major changes. In lieu of that, ad hoc provisions for differential treatment were achieved, such as the case of Article IV of the General Agreement on Tariffs and Trade (GATT) and its Enabling Clause.

$9 \quad$ This is not to say that they receive backing from regional peers. See Malamud (2011).

10 Narlikar \& Tussie (2016) explore the issue within the World Trade Organization. 
A second group of authors, among them Nye (2015), holds a different position. For them, the liberal order can adapt to the rise of developing countries, integrating differing views and moving towards an international architecture with shared leadership." Ikenberry (2015: 453) suggests that the contemporary scenario is one of "more continuity, integration and evolution in the existing order - rather than abrupt upheavals, revisionist agendas, and deep struggles over principles." For these scholars, international organizations are adaptable enough to embrace states with contrasting standpoints.

A third group of authors stresses concepts such as socialization to investigate the extent to which developing powers can be brought into the existing order. According to this view, the creation, diffusion, and internalization of norms play a prominent role. In the long run, China, India and Brazil would face the present normative boundaries and be socialized into existing norms. International organizations would shape the evolution of these countries' domestic policies, altering their individual interests and preferences, which could eventually lead to a more homogenous order (Checkel 2015). Other works (Acharya 2004; Xiaoyu 2012) have questioned such a one-sided approach to socialization and argue that developing powers can also be agents of socialization.

Overall, the tendency of these contributions is to place developing powers within fixed categories of "(soft)-revisionists," "agents/recipients of socialization," "partners," "balancers," "free-riders," "spoilers," and “bandwagons," among others. Beyond such classifications, these powers, as happens to their developed peers, can enact contradicting foreign policy behaviors. In contrast to perceptions that reify permanence, countries develop varying external traits in different issue-areas, partnerships, and negotiating arenas. Predictability and steadiness may not always be the imperative.

\section{Developing Powers in Multilateral Regimes}

One way to analyze how developing powers interact with the major parameters of the liberal order is by studying their foreign policy and negotiation strategies. As previously discussed, I do not accept that such powers rely on fixed strategies or on a "grand strategy." I assume that these states long for more representative positions in decision-making instances, and that they desire an international architecture that better reflects their interests.

Destradi (2010: 904) defines strategy as the "integration of political, economic and military aims for the preservation and realization of states' long-term

11 Buzan (2010) argues that although it may create tensions, the rise of China will be peaceful. Kupchan (2012) goes beyond, affirming tomorrow's world belongs to no one. 
interests." I suggest that strategic behavior can best be seen in ad hoc engagements. To differentiate that view from day-to-day politics, we can look for foreign policy initiatives that affect standing principles, norms, rules and decision-making procedures. Whether these are pro-status quo or pro-change proposals depend on the case. For matters of clarification, I analyze two concepts brought about by Brazil - responsibility while protecting and concentric circles - that produced consequences in their respective multilateral arenas, demonstrating the country's broader aspirations.

Examples of strategies involve proposing or blocking norms and rules, creating alternative institutions, and attempting to elect nationals to directive boards (Albuquerque 2016a). Burges (2013) shows that countries can assume the role of "consensus-builder" and gain legitimacy by acting as a bridge between the South and the North. Furthermore, by forming coalitions like the BASIC, developing countries can bring about new configurations of power in international organizations (Stuenkel 2015).

Although their behaviors suggest discomfort with what they see as an anachronistic order, there is no indication that developing powers aim to alter its normative foundations. The relative rise of countries such as China, India and Brazil does not challenge the basic principles and norms or intend to change the order per se. New provisions have not been substituted for existing principles, for example, the prohibition of threat or use of force, non-intervention, and common but differentiated responsibilities.

One could argue that these countries were the greatest beneficiaries of a more interdependent world. They could benefit from non-reciprocity, which allowed them to opt out or delay obligations. Their development status when these legal texts were negotiated is not the same as today. What is visible, therefore, is that such treaties did not accompany shifts in the distribution of power. For this reason, developing countries can sustain legalistic positions and reinforce the original provisions of conventions, avoiding or at least delaying the assumption responsibilities.

Even if developing powers expected to alter the existing order, they would not have the means to do so. Beyond lacking material capabilities, these players do not act as a unified group nor do they cooperate in a comprehensive manner. On the contrary, their external positions can vary according to the issue-area in question, the (regional) groupings they are attached to, and domestic circumstances. While their discourses are largely cooperative, their behaviors can diverge.

In sum, I do not concur with the notion that developing powers intend to revise the global order. In my view, they are not revisionists in essence. If such were the case, their foreign policies would need to display an intention to alter 
the core of the liberal order, namely its principles and norms. Such intentions would be identified not only in their discourse, but in their actions as well, which is not the case.

\section{What Do Strategies Convey?}

The foreign policy and negotiation strategies of developing powers can be analyzed using three indicators - two domestic and one structural. This framework is applied to Brazil's engagements in the negotiated regimes of climate change, and peace and security. The indicators are: regime structure, Brazil's domestic comparative advantages, and diplomatic expertise. The idea is to consider each of these indicators when assessing Brasília's proposals of concentric circles and responsibility while protecting. The underlying notion is that Brazil's foreign policy and negotiation strategies chart a path for the country's external action (Destradi \& Jakobeit 2015).

As for regime structure, institutional arrangements can enable or restrain the ability of a country to push forward its preferences. In many ways, they do both. When pursuing a multilateral approach, decision-makers bear in mind how the regime is characterized, power relations within the regime, and the degree of maneuverability a country has within the regime. The distribution of power within regimes can be considered a primary factor: whether a multilateral arena has more than one level of governance, if its players exert veto power, and if the decision-making procedures are accessible to all. The preliminary hypothesis is that the more hierarchical a regime is, the harder it will be for a developing country to act. Considering that developing countries do not hold decision-making authority - except for China at the UNSC - their ability to exert impact is diminished. This path is eased when developing countries hold authority. This argument was exemplified in 2011, when all the BRICS countries were members of the UNSC and voiced their opinions about NATO's intervention in Libya. In other regimes, these states face fewer institutional constraints.

With regard to domestic factors, these also contribute to an explanation of foreign policy and negotiation strategies. Authors from both liberal and neoclassical realist branches emphasize the role of domestic elements. Others reaffirm the relevance of domestic aspects in the decision-making process (Milner 1997). Leaders typically take into consideration material capabilities, societal support and the distributional effects of international agreements when making decisions. Domestic factors help to explain patterns of interdependence and study the extent to which international norms have 
been previously socialized. When calculating costs and benefits, decisionmakers look inward (Kahler 2013).

Domestic comparative advantages can underpin the international standing of a state. In nuclear non-proliferation talks, for instance, countries with nuclear weapons normally have more capacity to influence the agenda. What I call here comparative advantages, though, go beyond merely military or economic elements. A successful domestic policy, for example, can increase bargaining power. Moreover, countries gain advantages and enhance their negotiation positions when external players commend their national experiences.

The other domestic factor, diplomatic expertise, converges with the other two. Decision-makers translate preferences and advance national interests through diplomatic channels. When doing so, they ideally consider the advantages and disadvantages that result from domestic and structural elements. According to Adler-Nissen and Pouliot (2014), diplomatic skills are visible when representatives are able to convert their talents into influence. Generally, negotiators rely on the size of permanent missions, availability of legal expertise, information, use of media and knowledge. Although not easily quantifiable, this ability can be perceived in ad hoc negotiations, since delegates can sell national interests as collective interests and convince others. Translating such expertise into practice is crucial for a desired outcome.

These explanatory factors interact but are not equally present in a country's foreign policy strategy. Domestic factors may have more explanatory power than structural ones and vice versa. One hypothesis is that domestic factors play a more prominent role when an actor engages in multilateral regimes individually rather than collectively.

\section{A Legalistic Stance: Brazil's Concentric Circles Proposal}

This section presents Brazil's concentric circles proposal, launched at the climate change Conference of the Parties (COP)-20 in 2014 in Lima. With this proposition, Brazil expected to maintain the principle of common but differentiated responsibilities ( $С$ BR ), a central pillar of the climate regime. Brazil's proposal was well received and influenced not only the final document of COP-20, but also the subsequent COP-21. It is a legalistic position, for it exempts developing powers from broader obligations and refers to the United Nations Framework Convention on Climate Change (UNFCCC). Brazil's foreign policy strategy involved a novel reading of the multilateral climate regime, but one that did not blur the lines of differentiation. The analysis conducted here 
considers the three indicators already cited: regime structure, Brazil's domestic comparative advantages, and diplomatic expertise.

\section{The Structure of the Climate Change Regime}

The climate change regime is based on the UNFCCC, which was negotiated in 1992 and entered into effect in 1994, and on the Kyoto Protocol, adopted in 1997 and entered into effect in 2005. Its first commitment period lasted from 2008 to 2012, being further extended from 2013 to 2020 . From 1995 onward, parties convene annually at cops to revise legal gaps and propose climate-related topics. Kyoto determined binding emission reduction targets for industrialized states, distinguished as the Annex I parties, who should also support developing countries. ${ }^{12}$

This setup placed heavier responsibilities on the developed countries, reflecting a North-South separation. Throughout time, the regime suffered intense questioning, being accused of detachments from reality. The relative ascension of China, India and Brazil, who currently rank among the greatest emitters of GHG, was the main reason for such challenges, as these countries faced pressure both from the Annex I parties and the least developed states. ${ }^{13}$ While not having binding commitments, developing powers faced accusations of maintaining defensive positions and being free-riders.

Under pressure, Brazil, South Africa, India, and China assembled at the COP-15 (Copenhagen 2009) to form BASIC. ${ }^{14}$ The coalition changed the decision-making process, enhancing the bargaining power of the BASIC states. Defending the continuation of the principle of СвDR, they could avoid shifts towards an institutional setup that encompassed top-down obligations. With the 2015 Paris Agreement, the regime evolved into a voluntary setting, through which all countries assume Intended Nationally Determined Contributions (INDCs) to address climate change (Falkner, Stephan \& Vogler 2010).

\section{Brazil's Domestic Comparative Advantages}

Brazil's standing in the climate regime is relatively more comfortable in comparison to its peers in BASIC and Annex-I members. ${ }^{15}$ Brazil ranks among the

\footnotetext{
12 For the separation between developed and developing countries, see Hurrell \& Sengupta (2012); and Hochstetler \& Milkoreit (2015).

13 For GHG emissions, see http://data.worldbank.org/indicator/EN.ATM.CO2E.KT/countries.

14 For the negotiation groups under the UNFCCC, see http://unfccc.int/parties_and_obser vers/parties/negotiating_groups/items/2714.php.

15 For an overall account of Brazil's positions, see Vieira (2012).
} 
top $10 \mathrm{GH} \mathrm{G}$ emitters, ${ }^{16}$ but relies on a low carbon energy matrix that is primarily driven by land use, land use change, and forestry (LULUCF). From 2004 to 2012, annual deforestation rates in the Amazon decreased from $27.772 \mathrm{~km}^{2}$ to $4.571 \mathrm{~km}^{2}$. Deforestation increased between 2013 and 2016, but rates never surpassed 2007 levels. ${ }^{17}$

In 2010, emissions from LULUCF did not rank first for the first time in the country's historical series. ${ }^{18}$ In that year, emissions were composed of agriculture $(32 \%)$, energy $(29.2 \%)$, LULUCF $(27.5 \%)$, industrial processes $(7.1 \%)$, and waste management $(4.3 \%) .{ }^{19}$ Emissions are currently shifting towards the sectors of agriculture and energy, and the subsequent need for more accurate actions in these areas (Viola \& Basso 2015). In comparison to other BASIC members, the emissions of China, India and South Africa originate from the energy sector. Brazil's energy matrix, for its part, is composed of $41.2 \%$ renewables, which creates a distinguished position for the country when compared to global standards. ${ }^{20}$

In 2008, Brazil developed a National Climate Change Plan, which presented an array of measures to curb GHG emissions. It was followed in the next year by the National Climate Change Law, a regulation that established a National Policy on Climate Change (PNMC). The PNMC conveyed Brazil's compromise to deliver a voluntary reduction of between $36.1 \%$ and $38.9 \%$ of projected emissions by 2020, which served as the country's pledge at the COP-15. For the COP-21, Brazil was the only developing state to present an absolute reduction target in its INDC, ranging from $37 \%$ in 2025 to $43 \%$ in 2030 , below 2005 levels. ${ }^{21}$ Lastly, Brazil hosts the largest portion of the Amazon in its territory. This material resource makes the country an important stakeholder in the discussion on forests.

16 See http://cait.wri.org/. Also see http://edgar.jrc.ec.europa.eu/overview.php?v=CO2ts 1990-2015.

17 Among the reasons for this backlash are financial shortcuts for deforestation-curbing activities and the Forestry Code of 2012. See http://www.obt.inpe.br/prodes/prodes_ 1988_2015n.htm. For Brazil's GHG emissions, see http://www.mct.gov.br/upd_blob/o235/ 235580.pdf.

18 On Brazil's Third National Communication to the UNFCCC, see http://unfccc.int/national_reports/non-annex_i_natcom/submitted_natcom/items/653.php.

19 See http://sirene.mcti.gov.br/web/guest/emissoes-em-co2-e-por-setor.

20 See http://www.brasil.gov.br/economia-e-emprego/2016/og/energia-renovavel-mantemcrescimento-robusto.

21 Seehttp://www4.unfccc.int/Submissions/InDC/Submission\%2oPages/submissions.aspx. For a comparison of country emissions and INDCs, see http://climateactiontracker.org/ indcs.html. 


\section{Diplomatic Expertise}

Brazil's overall position in the regime evolved from mostly defensive postures to more pragmatic involvement. Prior to the Kyoto Protocol, Brazil championed the proposal of the Clean Development Mechanism, which combines the reduction of emissions by Annex-I parties with cooperation towards their non-Annex-I peers. In 2009, the country sponsored the formation of BASIC, which helped the beleaguered Copenhagen Accord to come to a conclusion. Throughout time, Brazil relied on its domestic comparative advantages and on the country's standing in the regime to uphold legalistic stances towards the preservation of the principle of СвDR. In 2014, its negotiators framed the concept of concentric circles, a corollary to CBDR.

With regard to the decision-making process in Brazil, its negotiators are mostly diplomats from the Ministry of External Relations (MRE), commonly known as Itamaraty, and officials from the Ministry of the Environment (MMA). They are highly specialized individuals who make their careers either at Itamaraty's Division of Climate, Ozone and Chemical Safety, or at the MMA. Convening in successive cops, these representatives master negotiation skills and know how to deal with the intricacies of the regime, which is crucial for influencing agreements. These conditions grant Brazil power in the negotiations.

Other ministries are also involved in defining Brazil's positions and convene with Itamaraty before the cops. Moreover, non-governmental organizations (NGO) pressure the government directly and through the media. As they represent groups with clashing interests, these bureaucratic and civil society actors can complicate decision-making. Throughout the years, however, Itamaraty, together with the MMA has been able to control disputes between internal actors. These hurdles are not always apparent to foreign observers. Lastly, Brazil is one of the countries with the largest delegations at the cops. While this does not automatically translate into leverage, a big delegation can aid negotiators when dealing with technical themes. ${ }^{22}$

\section{Brazil's Concentric Circles Proposal}

Brazil's concentric circles proposal demonstrates the interaction of the country with the principle of CBDR. It was first presented at the UNFCCC Secretariat in 2014, prior to the organization of the COP-20 later that year in Lima. ${ }^{23}$ At that moment, parties prepared the post-Kyoto framework and disputed the

\footnotetext{
22 Seehttp://www.carbonbrief.org/analysis-which-countries-have-sent-the-most-delegatesto-cop21. Also, see http://unfccc.int/resource/docs/2016/cop22/eng/misco2po1.pdf.

23 See https://www.theguardian.com/environment/2014/dec/04/brazil-climate-talks-emis sions-agreement.
} 
future of the regime. Some asserted that differentiation in annexes was no longer suitable, since developing countries now rank among the top G HG emitters. Others, Brazil among them, went for a legalistic view, stating that the original framework of the UNFCCC should be updated with a nuanced interpretation of differentiation.

The concentric circles approach divides countries in three circles that converge in a common effort to advance agreement (Voigt \& Ferreira 2016). ${ }^{24}$ The inner circle unites countries with economy-wide absolute targets (the former Annex-I parties). Apart from this central circle, other parties could choose which circle they would be included in. Countries in the second circle are expected to proceed with GHG cuts in all sectors of their economies, but not absolute ones. ${ }^{25}$ Developing countries such as BASIC members would fit in this category. The third circle groups countries that pursue non-economy-wide actions.

Brazil's strategy can be viewed as promoting three objectives. First, it acted defensively to keep СвDR as the main feature of the regime. By doing so, it could minimize pressures and postpone obligations. Second, the concentric circles is a realistic way to represent the current division of power between developed and developing states. Since Brazil and others have ascended, but not yet achieved a state of development comparable to the wealthiest countries, they would remain in an intermediate position. Following this view, Brazil's initiative sought to make the regime reflect reality, going beyond the strict separation between Annex-I and non-Annex-I parties. By sitting in the middle, BASIC countries could also receive financial and technical cooperation. Third, Brazil aspired to behave as a consensus-builder, bringing together different positions and, at the same time, respecting the foundational principle of the climate regime.

With reference to the three indicators that comprise Brazil's strategy, the structure of the climate regime played a crucial role in the concentric circles proposal. The climate regime is a non-hierarchical setting, in which all players can enable or veto an accord. Although some countries have more bargaining power than others and many decisions are reached in restricted meetings,

24 The document contains a graphic representation of the proposal of concentric circles. See http://www4.unfccc.int/submissions/Lists/OSPSubmissionUpload/73_99_ 130602104651393682-BRAZIL\%2oADP\%2oElements.pdf. Also, see Rajamani (2016).

25 These can be per capita targets, intensity targets or halting emissions compared to a Business as Usual (BaU) scenario. Business as usual are emissions that would occur if no efforts were made to reduce them. 
Brazil could influence the decision-making process, strategically playing with the regime's division in annexes.

When it comes to Brazil's domestic comparative advantages, the country's INDC fits between the central and the second concentric circle. ${ }^{26}$ Pragmatically, Brazil made a proposal that it thought could be accepted. Brazilian negotiators engaged creatively with the main principle of the regime. Although Brazil was not the only one proposing new visions on differentiation - as New Zealand and Switzerland defended diverse views - its diplomatic ability prevailed.

\section{Brazil and the Peace and Security Regime}

This section analyzes Brazil's foreign policy in the multilateral peace and security regime. More specifically, it examines the proposal of responsibility while protecting $(\mathrm{RwP})$, a corollary to the norm of responsibility to protect $\left(\mathrm{R}_{2} \mathrm{P}\right)$ and one of the foundations of the regime. Brazilian negotiators promoted RwP in the context of UNSC resolution 1973/2011, which gave way to NATO's intervention in Libya.

\section{The Structure of the Regime}

The multilateral peace and security regime is based not only on the United Nations system and its organs, but also on regional organizations and alliances of collective security. Responsible for maintaining peace and security, the UNSC is composed of five permanent members with veto power (the $\mathrm{P}_{5}$ ). Its arrangement reflects the long-lasting principle of balance of power and establishes a hierarchical division that is constantly subject to question. Beyond the $\mathrm{P}_{5}$, ten non-permanent members populate the council and they have a hard time influencing debates. Recurrently, Brazil, South Africa and India oppose what they see as an exclusive arrangement, calling instead for an enlarged membership that reflects the current distribution of power.

The norm of $\mathrm{R}_{2} \mathrm{P}$ equates sovereignty with respect for human rights and state responsibility (Foot 2011; Doyle 2015). It aims to prevent mass atrocities such as ethnic cleansing, genocide, war crimes and crimes against humanity. $\mathrm{R}_{2} \mathrm{P}$ is founded on three pillars: (1) each state carries the primary responsibility for protecting its population, (2) the international community should encourage and help states to exert that responsibility, and (3) the international community has the responsibility to take timely and decisive action to prevent

26 See http://www4.unfccc.int/submissions/IndC/Published\%2oDocuments/Brazil/1/ BRAZIL\%2oiNDC\%2oenglish\%2oFINAL.pdf. 
mass atrocities. If a state manifestly fails to protect its populations, collective action can be taken (United Nations 2005). ${ }^{27}$ Since 2006, the UNSC has invoked $\mathrm{R}_{2} \mathrm{P}$ in more than 45 resolutions, ${ }^{28}$ which shows the state of disarray of today's global order and the central role the UNSC plays. The 2011 NATO-led intervention in Libya, as discussed below, demonstrates the operationalization of the third pillar of R2P. Brazil's proposal of RwP was presented in this context.

\section{Brazil's Domestic Comparative Advantages}

Brazil is a traditional contributor to peacekeeping operations (PKO) and from 1947 to 2015 it contributed approximately 50,000 personnel working under the auspices of the UN. From this total, $87 \%$ participated in PKOs since the end of the Cold War (Hamann 2016). The United Nations Stabilization Mission in Haiti (MINUSTAH) alone involved more than 30,000 Brazilian troops in addition to the participation of 15 other states. MINUSTAH exemplifies Brazil's aspirations to exert a more prominent role in the peace and security regime. More recently, efforts have been undertaken to align Brazil's foreign policy with security imperatives (Albuquerque 2016b).

After Brazil's democratization, its armed forces received new guidance under a civilian-led Ministry of Defense and slowly regained bureaucratic space. Brazil's military expenditure from 2002 to 2016 ranged from $1.9 \%$ to $1.3 \%$ of its GDP. Between 2002 and 2014, military spending increased $30 \%$ and then decreased due to an economic slowdown. ${ }^{29}$ Such changes created difficulties for prioritized projects, including the Navy's nuclear program, the Army's strategy to protect the Amazon, and the Air Force's F-X2 project. Together, these projects involve 327,00o military personnel (Brazil 2012). Domestic problems, however, tarnish Brazil's image in the pursuit of peace and security. In 2015 alone, more than 58,00o assassinations occurred, a death toll higher than in war-torn Syria that year. ${ }^{30}$

With regard to the domestic decision-making process, the ministries of External Relations and Defense are responsible for issues related to peace and

27 See https://documents-dds-ny.un.org/doc/UnDOc/GEN/No5/487/6o/PDF/No54876o.pdf? OpenElement, especially paragraphs 138-140.

28 See http://www.globalr2p.org/about_r2p. Also, see Bellamy (2011); and Mani \& Weiss (2011).

29 See https://www.sipri.org/databases/milex.

30 See http://www.forumseguranca.org.br/wp-content/uploads/2017/01/Anuario_Site_2701-2017-RETIFICADO.pdf. The grim scenario for human rights is coupled with Brazil's challenging criminal justice system. See http://www.global.org.br/wp-content/uploads/ 2016/10/RPU-Sistema-Prisional.pdf. 
security. Coordination between them is difficult and can vary depending on the topic (Kenkel 2017). ${ }^{31}$ As non-permanent members of the UNSC, Brazil's diplomats reinforce the importance of preventive diplomacy and peaceful resolution of disputes. They frequently underline the notion that Brazil has been at peace with its neighbors since the War of the Triple Alliance (1864-1870).

\section{Brazil's Diplomatic Expertise}

After Japan, Brazil has occupied a non-permanent seat on the UNSC more than any other country, comprising a total of ten biennial terms. During its last mandate from 2010-2011, Brazil received 182 out of 183 possible votes, which denotes recognition by its peers and Brazil's experience in dealing with peace and security issues and with council functions. In general terms, Brazil's strategy emphasizes the interdependence between peace, security and development. Its negotiators are skeptical of an unbridled enlargement of the concept of security, considering that the notion of human security can be manipulated. Brazil's strategy also emphasizes the belief that preventive diplomacy is crucial to avoid mass atrocities (Viotti, Dunlop \& Fernandes 2014).

The country takes a critical stance towards the use of the veto, considering it a symbol of failed talks and a potential source of friction among the $\mathrm{P}_{5}$ (Fonseca Jr. 2008). It views the veto as a privilege that circumvents the sovereign equality of states and is used to achieve self-centered interests (Brasil 2007: 198).

Brazil's voting behavior is mostly in line with the majority of the UNSC, ranging from a $100 \%$ accordance rate in 1999 to an $80 \%$ in 2011 (Uziel 2015). Considering Brazil's previous terms, it abstained three times in 2004-05, and twice in 2010-11. It voted negatively in 1999 and in 2010, but the 2010 vote was the only vote that did not reflect the majority. Brazilian abstentions express dissatisfaction, but are knowingly cast without hope of defeating resolution drafts the country does not agree with. Since the early 1990s, Brazil follows the practice of abstaining instead of voting no, "unless the issue at stake is of utmost importance to its foreign policy" (Uziel 2015: 70). ${ }^{32}$

In 1999, Brazil voted negatively together with 11 other members on a draft resolution that demanded the cessation of the use of force against Yugoslavia. ${ }^{33}$ In the 2004-05 term, Brazil abstained from resolution 1559 on Lebanon. ${ }^{34}$ In

31 See http://www.providingforpeacekeeping.org/2014/04/o3/contributor-profile-brazil/.

32 To a large extent, voting no can have a larger diplomatic cost and place the country in the spotlight as a non-cooperative player. See Bailey \& Daws (1998); and Amorim Neto (2011).

33 See http://www.un.org/press/en/1999/19990326.sc6659.html.

34 See https://www.un.org/press/en/2004/sc8181.doc.htm. 
2005, it abstained from resolution 1646 , which ensured a permanent place for the $\mathrm{P}_{5}$ on the newly created Peacebuilding Commission, and from resolution 1593 on Sudan. ${ }^{35}$ In 2010, Brazil voted with Turkey against resolution 1929, which imposed additional sanctions on Iran's nuclear program. On this occasion, Brazil protested the insufficient disposition of the $\mathrm{P}_{5}$ to share the decision-making process (Amorim 2015). Lastly, in 2011 the country abstained from a draft resolution on Syria.

\section{Brazil's "Responsibility while Protecting" Strategy}

In the midst of sweeping regional transformations, Libya was consumed by a longstanding crisis in 2011 that required UNSC intervention. First, resolution 1970 demanded an end to the domestic strife and affirmed the council's readiness to take necessary "additional appropriate measures." ${ }^{36}$ Spiraling violence created the political momentum for subsequent resolution 1973, which classified mass atrocities as possible crimes against humanity, tightened sanctions and imposed a no-fly zone. It authorized member states to take "all necessary measures" to protect civilians, making $\mathrm{R}_{2} \mathrm{P}$ operational. ${ }^{37}$ With Brazil, India, China, Germany and Russia abstaining, this resolution had only weak support. To justify its vote, Brazil highlighted the need for a peaceful resolution and advised against intervention on the basis of unintended consequences. Negotiators argued that the resolution went beyond its original provisions, which could cause "more harm than good to the very same civilians we are committed to protecting." ${ }^{38}$

In direct response to the consequences of the resolution, President Dilma Rousseff presented the concept of responsibility while protecting ( $\mathrm{RwP})$ at the General Assembly. In November 2011, Brazil presented the idea in a debate on the protection of civilians in armed conflicts and two days later circulated a conceptual note explaining RwP and defining it as a corollary rather than an opposition to $\mathrm{R}_{2} \mathrm{P} .{ }^{39}$ Brazil's intention was not to deny $\mathrm{R} 2 \mathrm{P}$, but to control the use of force within specific parameters, reinforcing cooperation and the

\footnotetext{
35 See http://unscr.com/en/resolutions/doc/1646.

36 Although Brazilian officials defended the resolution, they expressed reservations to its operative paragraph 6, which allows for exemptions from jurisdiction of nationals from non-state parties at the Rome Statute (Stahn 2012). See http://www.nato.int/nato_static/ assets/pdf/pdf_2011_02/20110927_110226-UNSCR-1970.pdf.

37 See http://www.nato.int/nato_static_fl2014/assets/pdf/pdf_2011_03/20110927_110311-UN SCR-1973.pdf.

38 See https://www.un.org/press/en/2011/sc10200.doc.htm.

39 For the conceptual note, see http://responsibilitytoprotect.org/concept-paper-_rwp(1) .pdf. On RwP, see Leme (2015); and Kenkel \& Stefan (2016).
} 
need for states to respect civilians (Tourinho, Stuenkel \& Brockmeier 2016). In the conceptual note, Brazil upheld a legalistic stance, reiterating the material, temporal, and formal limitations to R2P. Whenever exerting its responsibility to protect, a country should observe its responsibility while protecting, which underlines the inter-relation between the norm and its corollary. Regarding the three pillars of $\mathrm{R}_{2} \mathrm{P}, \mathrm{RwP}$ aims to strengthen the first two and to regulate the last one. In a nutshell, $\mathrm{RwP}$ is a call for collective responsibility. The United States, the United Kingdom and France did not indicate initial support, seeing RwP as an impediment to $\mathrm{R}_{2} \mathrm{P}$.

Regarding the three indicators that compose Brazil's strategy, I argue that the structure of the regime, and the country's diplomatic expertise played a decisive role. Concerning the structure of the regime, Brazil made use of its non-permanent membership to promote RwP. While Rousseff's speech raised some attention, Brazil's conceptual note created more awareness in the political landscape and within the academic field. Furthermore, timing was ripe for the issue to gain importance. However, the conceptual debate on RwP lost momentum when Brazil left the Unsc.

As for domestic elements, Brazil's comparative advantages did not play a role in explaining RwP. Brazil's experience with PKOs and history of regional peace are normally evoked by its negotiators when presenting the country as a promoter of preventive diplomacy and cooperation. In the case of RwP, however, there is no clear connection between these dimensions. Lastly, the expertise of its diplomats was crucial for RwP to come into existence. As Benner (2013) affirms, the R2P debate previously advanced similar concepts, but Brazil was the one to package them under the RwP label.

\section{Conclusions}

By analyzing two case studies, this article shows that Brazil's conduct in the multilateral regimes of climate change, and peace and security attempted to strengthen existing principles and norms. Its behaviors contradict classifications of developing powers as challengers that will necessarily bring disarray to the liberal order and propose thorough change or substitution of normative elements. As far as such realist interpretations fall short in explaining current dynamics, assertions that these powers are subject to socialization are also weak.

The evidence presented demonstrates that Brazil actively engaged in the multilateral architecture, proposing new readings of old principles and norms, and emphasizing the provisions of original treaties and conventions. The ideas of concentric circles and responsibility while protecting influenced regime 
debates on climate change and peace and security, portraying Brazil as a cooperative player. Interestingly, the developed powers were the ones trying to revise the original provisions of the climate change regime. In the case of RwP, they did not fully welcome Brazil's proposal.

Three indicators were considered in the analysis of Brazil's negotiation strategies: regime structure, domestic comparative advantages, and diplomatic expertise. While all these factors were relevant in explaining Brazil's proposal of concentric circles, the same cannot be said regarding RwP. The crucial variable for the latter is regime structure. Brazil was only able to move RwP forward when it held non-permanent membership at the UNSC. Making use of this role, its negotiators could engage with $\mathrm{R}_{2} \mathrm{P}$ and organize the notion of $\mathrm{RwP}$ amidst the unfolding Libyan crisis. When Brazil left the council, the debate lost momentum, but it still influences discussions on humanitarian intervention. One reading is that unwillingness by some of the $\mathrm{P}_{5}$ to accept RwP made its membership on the council shorter. Another interpretation is that Brazil had difficulties delivering the message that $\mathrm{RwP}$ was not contrary to $\mathrm{R} 2 \mathrm{P}$. Future efforts can better address this issue.

When it comes to the concentric circles, all explanatory factors played an important role. Here, Brazil can play with the regime's division in annexes and interact with the principle of $\mathrm{CBDR}$, proposing a new concept that maintains a pragmatic differentiation of responsibilities between developed and developing countries. Brazilian negotiators can translate the inner tensions of the regime into a proposal that matches the country's domestic advantages. The concentric circles went beyond the COP-20, influencing the Paris Agreement. ${ }^{40}$

\section{References}

Acharya, Amitav (2004). "How ideas spread? Whose norms matter? Norms localization and institutional change in Asian regionalism." International Organization 58: 239-275.

Adler-Nissen, Rebecca and Vincent Pouliot (2014). "Power in Practice: Negotiating the International Intervention in Libya." European Journal of International Relations 20, 4: 889-911.

Albuquerque, Felipe Leal Ribeiro de (2016a). "A Cooperative Global South? Brazil, India, and China in Multilateral Regimes." Carta Internacional 11, 1: 163-187.

40 See https://unfccc.int/resource/docs/2015/cop21/eng/logro1.pdf. 
Albuquerque, Felipe Leal Ribeiro de. (2016b). "Navigating the Atlantic: Brazil's defense engagements with Africa in the South Atlantic." PRIMO Working Paper Series 4, 4:1-48.

Amorim, Celso (2015). Teerã, Ramalá e Doha - Memórias da Política Externa Ativa e Altiva. São Paulo: Benvirá.

Amorim Neto, Octavio (2011). De Dutra a Lula: a Condução e os Determinantes da Política Externa Brasileira. Rio de Janeiro: Elsevier.

Bailey, S. D. and S. Daws (1998). The Procedure of the UN Security Council. Oxford: Oxford University Press.

Benner, Thorsten (2013). "Brazil as a Norm Entrepreneur: the 'Responsibility while Protecting' Initiative." GPPi Working Paper: 1-11.

Brasil (2007). Repertório de Política Externa: Posições do Brasil. Ministério das Relações Exteriores. Secretaria de Planejamento Diplomático. Brasília: FUNAG.

Brazil (2012). Defense White Paper. Brasília: Ministry of Defense.

Bellamy, Alex J. (2011). "Libya and the Responsibility to Protect: the Exception and the Norm." Ethics \& International Affairs 25, 3: 263-269.

Burges, Sean (2013). "Brazil as a Bridge between Old and New Powers?" International Affairs 89, 3: 577-594.

Buzan, Barry (2010). "China in international society: is 'peaceful rise' possible?" Chinese Journal of International Politics 3, 1: 5-36.

Checkel, Jeffrey T. (2015). "Mechanisms, process, and the study of international institutions," in Andrew Bennett and Jeffrey T. Checkel, editors, Process Tracing: from Metaphor to Analytic Tool. Cambridge: Cambridge University Press.

Destradi, Sandra (2010). "Regional Powers and Their Strategies: Empire, Hegemony, and Leadership." Review of International Studies 36, 4: 903-930.

Destradi, S. and C. Jakobeit (2015). "Global Governance Debates and Dilemmas: Emerging Power's Perspectives and Roles in Global Trade and Climate Governance." Strategic Analysis 39, 1: 60-72.

Doyle, Michael (2015). The Question of Intervention: John Stuart Mill and the Responsibility to Protect. New Haven: Yale University Press.

Falkner, R., S. Hannes, and J. Vogler (2010). "International Climate Policy after Copenhagen: towards a 'Building Blocks' Approach.” Global Policy 1: 252-262.

Finnemore, M. and K.t Sikkink (1998). "International Norm Dynamics and Political Change." International Organization 52, 4: 887-917.

Fonseca Jr., Gelson (2008). O interesse e a Regra. São Paulo: Paz e Terra.

Foot, Rosemary (2011). "The Responsibility to Protect $(\mathrm{R} 2 \mathrm{P})$ and its Evolution: Beijing's Influence On Norm Creation in Humanitarian Areas." St Antony's International Review 2, 6: 47-66.

Hamann, Eduarda Passarelli (2016). "O Brasil e as Operações de Manutenção da Paz: a Consolidação de um Novo Perfil?” Cadernos Adenauer XVII, 4: 95-110. 
Hochstetler, Kathryn and Manjana Milkoreit (2015). "Responsibilities in Transition: Emerging Powers in the Climate Change Negotiations." Global Governance 21: 205-226.

Hurrell, Andrew (2002). "Norms and ethics in international relations," in Walter Carlsnaes, Thomas Risse and Beth A. Simmons editors, Handbook of International Relations. London: SAGE.

Hurrell, Andrew (2007). On Global Order: Power, Values, and the Constitution of International Society. Oxford: Oxford University Press.

Hurrell, Andrew and Sandeep Sengupta (2012). "Emerging powers, North-South relations and global climate politics." International Affairs 88, 3: 463-484.

Ikenberry, John G. (2015). "The Future of Liberal World Order." Japanese Journal of Political Science 16, 3: 450-455.

Kahler, Miles (2013). "Rising Powers and Global Governance: Negotiating Change in a Resilient Status Quo." International Affairs 89, 3: 711-729.

Kenkel, K. M. and C. G. Stefan (2016). "Brazil and the responsibility while protecting initiative: norms and the timing of diplomatic support." Global Governance 22: 41-58.

Krasner, Stephen D. (1983). International Regimes. Ithaca: Cornell University Press.

Kupchan, Charles A. (2012). No One's World: The West, the Rising Rest, and the Coming Global Turn. Oxford: Oxford University Press.

Leme, João Marcos Senise Paes (2015). "A Intervenção na Líbia, a 'Responsabilidade de Proteger' e a 'Responsabilidade ao Proteger.' Cadernos de Política Exterior 1, 1: 91-115.

Malamud, Andrés (2011). "A Leader Without Followers? The Growing Divergence between the Regional and Global Performance of Brazilian Foreign Policy." Latin American Politics and Society 53, 3: 1-24.

Mani, Rama and Thomas G. Weiss (2011). Responsibility to Protect: Cultural Perspectives in the Global South. New York: Routledge.

Mearsheimer, John J. (2001). The Tragedy of Great Power Politics. New York:W. W. Norton \& Company.

Milner, Helen V. (1997). Interests, Institutions, and Information: Domestic Politics and International Relations. Princeton: Princeton University Press.

Narlikar, A. and D. Tussie (2016). "Breakthrough at Bali? Explanations, Aftermath, Implications." International Negotiation 21, 2: 209-232.

Nye, Joseph S. (2015). Is the American Century Over? Cambridge: Polity Press.

Patrick, Stewart (2010). "Irresponsible Stakeholders? The Difficulty of Integrating Rising Powers." Foreign Affairs 89, 6: 44-53.

Puchala, D. J. and R. F. Hopkins (1983). "International Regimes: Lessons from Inductive Analysis," in Stephen D. Krasner, editor, International Regimes. Ithaca: Cornell University Press. 
Rajamani, Lavanya (2016). "Ambition and Differentiation in the 2015 Paris Agreement: Interpretative Possibilities and Underlying Politics." International \& Comparative Law Quarterly 65, 2: 493-514.

Ruggie, John G. (1982). "International Regimes, Transactions, and Change: Embedded Liberalism in the Postwar Economic Order." International Organization 36, 2: 379415 .

Stahn, Carsten (2012). "Libya, the International Criminal Court and complementarity, a test for 'shared responsibility.'” Journal of International Criminal Justice 10, 2: 325-349.

Stuenkel, Oliver (2015). The BRICS and the Future of the Global Order. London: Lexington Books.

Tourinho, M., O. Stuenkel, and S. Brockmeier (2016). “'Responsibility while Protecting”: Reforming R2P Implementation." Global Society 30, 1:134-150.

Uziel, Eduardo (2015). "The Vote of Brazil in the United Nations Security Council (19462011) and the Role of Elected Members in the Decision-making Process." Jios 6, 2: $67-84$.

Vieira, Marco A. (2012). "Brazilian Foreign Policy in the Context of Global Climate Norms." Foreign Policy Analysis 9, 4: 1-18.

Viola, E. and L. Basso (2015). "Brazilian Energy-climate Policy and Politics towards Low Carbon Development." Global Society 29, 3: 427-446.

Viotti, M. L. R., M. R. C. Dunlop and L. L. G. N. Fernandes (2014). O Brasil no Conselho de Segurança da ONU: 2010-2011. Brasília: FUNAG.

Voigt, C. and F. Ferreira (2016). “'Dynamic Differentiation': the Principles of CBDR-RC, Progression and Highest Possible Ambition in the Paris Agreement." Transnational Environmental Law 5, 2: 285-303.

Xiaoyu, Pu (2012). "Socialization as a Two-way Process: Emerging Powers and the Diffusion of International Norms." The Chinese Journal of International Politics 5 , 4: $341-367$. 